\title{
Fomitopsis minutispora Rajchenb., a new record of Polyporales for the Chilean mycobiota
}

\author{
Fomitopsis minutispora Rajchenb., nuevo registro de Polyporales para la micobiota \\ chilena
}

\author{
Pablo Sandoval ${ }^{1,2} \&$ Mario Rajchenberg ${ }^{3}$ \\ ${ }^{1}$ Departamento de Sanidad Vegetal, Facultad de Ciencias Agronómicas, Universidad de Chile. \\ ${ }^{2}$ BIOTA, Gestión y Consultorías Ambientales Limitada, Roberto Owen 0267, La Florida, Santiago, Chile. \\ ${ }^{3}$ Departamento de Protección, Centro de Investigación y Extensión Forestal Andino Patagónico (CIEFAP), C.C. 14, 9200 \\ Esquel, Chubut, Argentina \\ psandoval@u.uchile.cl; agropablo@gmail.com; mrajchenberg@ciefap.org.ar
}

\begin{abstract}
RESUMEN
Se registra Fomitopsis minutispora Rajchenb. (Polyporales, Basidiomycota) por primera vez en Chile. Los basidiomas de la especie fueron hallados sobre troncos caídos, siempre en bosques con presencia del género Nothofagus en la Región de los Ríos. Se presenta una breve descripción, fotografías de la especie y una clave para diferenciar los políporos de basidiomas perennes y pileados más comunes en los bosques de Nothofagus de Chile.
\end{abstract}

During field trips near Lake Maihue in Futrono, Región de los Ríos, Southern Chile, in an area between $40^{\circ} 8^{\prime}$ and $40^{\circ} 15^{\prime}$ 'south latitude and $71^{\circ} 53^{\prime}$ and $71^{\circ} 60^{\prime}$ 'west longitude, perennial and pileate basidiomata of a species of Polyporales (Basidiomycota) were found at several collecting points in Nothofagus obliqua (Mirb.) Oerst. and Nothofagus dombeyi (Mirb.) Oerst. forests. These basidiomata differed from other perennial polypores known from Chile by its association with a brown rot in the substrate and by morphological traits. The collections were identified as Fomitopsis minutispora Rajchenb., a species belonging to family Fomitopsidaceae (Kirk et al. 2008) which previously was only known from the lake Lácar basin in southern Argentina. Basidiomata were collected and processed following Ryvarden \& Gilberston (1993) and documented in situ and in laboratory by digital colour photographs with Nikon Coolpix L1 and P8 cameras. In laboratory, macroscopical and microscopical features were studied on material mounted in water, $3 \%$ $\mathrm{KOH}$ and Melzer's reagent with transmitted light with phase contrast (Axiostar plus, Carl Zeiss, Germany) and stereoscopic microscope. For preservation, the specimens were desiccated for $48 \mathrm{~h}$ at ventilated oven and deposited at authors' personal collections and at the fungal collection of the Natural History Museum Santiago, Chile (SGO).

TAXONOMY

Fomitopsis minutispora Rajchenb. Mycotaxon 54: 441, 1995.

Type: Argentina, Provincia de Neuquén, National Park
Lanín, Lago Queñi, leg. M. Rajchenberg 10851, 27-IV-1994 (BAFC 33360, Holotype!).

Chilean collections corresponded well to descriptions by Rajchenberg (1995, 2006). Basidiomata perennial, resupinate to pileate (Fig. 1); when pileate generally triquetrous, up to $18 \times 10 \times 11 \mathrm{~cm}$, coriaceous to ligneous; frequently gregarious; pilear surface sulcate, smooth to rugulose and glabrous, dark brown and indurated (Fig. 1a, 1b, 1c); context light pinkish brown with variable number of tube layers (Fig. 1c), almost absent in resupinate specimens (Fig. 1d); hymenial surface white to cream-coloured when fresh, sometimes with pinkish tones, turning beige to straw yellow when drying, pores 6.5-7.5/mm (Fig. 1b, 1d, 1f); hyphal system di-trimitic, generative hyphae with clamp connections, 2-3.5(-4) $\mu \mathrm{m}$ diam., thin-walled, hyaline to light brown walls (Fig. 2d), skeletal hyphae unbranched, sometimes with short lateral branches, 2-4 $\mu \mathrm{m}$, thick-walled, hyaline to light brown (Fig. 2e); binding hyphae branched, 2-3.5 $\mu \mathrm{m}$ diam., scarce or lacking; Basidia clavate, 13-15 x 5-6 $\mu \mathrm{m}$ (Fig. 2b); basidiospores ellipsoid to short cylindric, 4-4.5 x 2-3 $\mu \mathrm{m}$, thin and hyaline walls, IKI- and acyanophilous (Fig. 2a); cystidia lacking; cystidioles fusoid to lageniform, slightly ventricose, thin to thick walled, with a terminal, hyphoid prolongation of variable length that grows into the tube (Fig. 2c); associated with a brown rot.

Basidiomata of $F$. minutispora are macroscopically easily 
distinguishable due to its indurated pileal surface, generally triquetrous shape, light pinkish brown and woody context, and whitish to straw yellow hymenial surface. In relation to habitat and substrate, basidiomata were found on rotting trunks, within a forest matrix of Nothofagus obliqua (roble) and Nothofagus dombeyi (coigüe), frequently accompanied by hardwood species such as Aextoxicon punctatum Ruiz \& Pav. (olivillo), Eucryphia cordifolia Cav. (ulmo), Laureliopsis philippiana (Looser) Schodde (tepa) and several Myrtaceae species which, phytogeographically, is immersed in the "Región del Bosque Laurifolio" (Gajardo 1994). Rajchenberg $(1995,2006)$ recorded it on trunks of Nothofagus dombeyi, $N$. obliqua and N. alpina (Poepp. \& Endl.) Oerst. (syn:
$N$. nervosa (Phil.) Krasser), suggesting the two latter as preferential substrates, where it may cause significant damage to the standing tree. F. minutispora is distributed in Southern Argentina and Chile, associated to Nothofagus forests. Until now it was only known from lake Lácar basin in Argentina. It should be mentioned that both, the Argentinean and the Chilean collecting areas are at a linear distance of $25-40 \mathrm{~km}$, in similar latitudes (Fig. 3) and within the phytogeographical context of the South American temperate forest, specifically in the forest type of Nothofagus obliqua - N. alpina - N . dombeyi (Donoso 1993). Rajchenberg (2006) pointed out that, apparently, the species is restricted to the relatively temperate climate zones in the Patagonian Andean region.



Figure 1. Fomitopsis minutispora: a, b. Group of basidiomata on fallen tree; a, b, e. Typically triquetrous basidioma with indurated and sulcate pilear surface; b, d, f. Whitish to yellowish hymenial surface; c. Section through basidioma exposing pinkish brown context and tube layer; $d$. Resupinate basidiomata. Bar $=2 \mathrm{~cm}$.

Figura 1. Fomitopsis minutispora: a, b. Grupo de basidiomas sobre un árbol caído; a, b, e. Basidioma típicamente triquetro con una superficie pilear endurecida y surcada; b, d, f. Superficie himenial blanquizca a amarillenta; c. Sección del basidioma exponiendo el contexto pardo rosáceo y el estrato de tubos; d. Basidiomas resupinados. Barra $=2 \mathrm{~cm}$. 
Key to Perennial AND PILEATE POlypores most COMmonly found in Chilean Nothofagus forest

1. Spores double walled

Ganoderma australe (Fr.) Pat.

1 '. Spores simple walled

Fomitopsis minutispora Rajchenb.

2. Context light pinkish brown associated wood-rot brown.

2'. Context woody brown, associated wood-rot white.

..3

3. Pilear surface lacking a crust, hymenial setae present ....

Phellinus senex (Nees \& Mont.) Imazeki

3'. Pilear surface covered by a crust, hymenial setae lacking

Phellinus andinopatagonicus (J.E. Wright \& J.R. Deschamps) Ryvarden

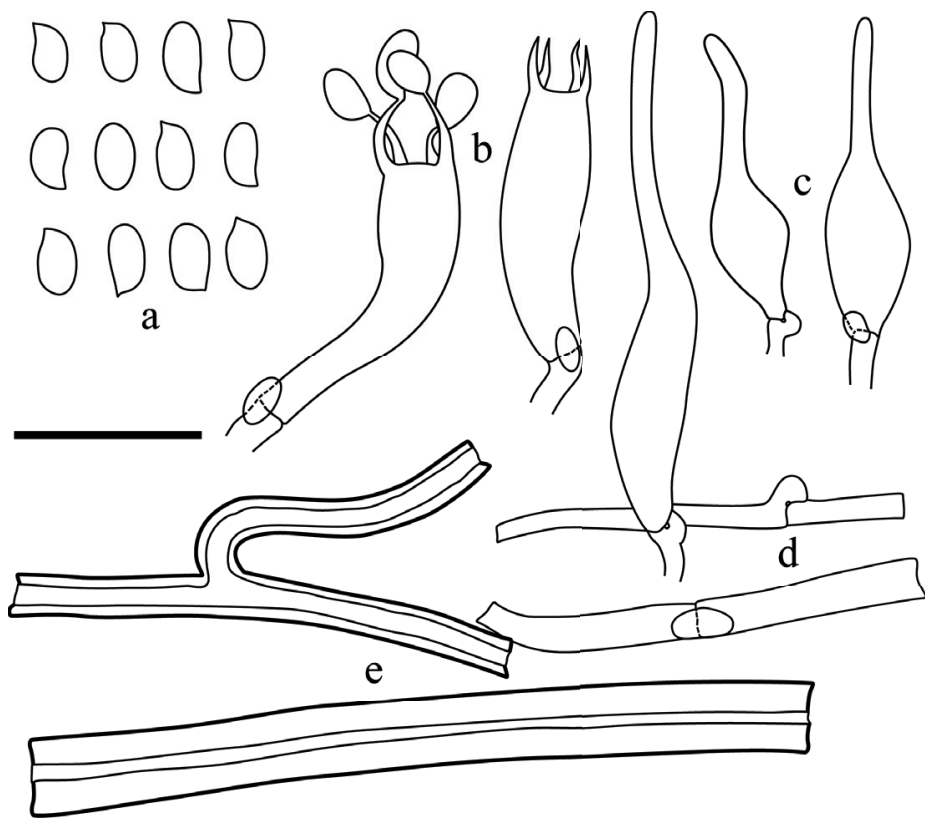

Figure 2. Fomitopsis minutispora (P. Sandoval 184, SGO160000), microscopic characters: a, basidiospores. b, basidia. c, cystidioles. d, generative hyphae. e, skeletal hyphae. Bar $=10 \mu \mathrm{m}$.

Figura 2. Fomitopsis minutispora (P. Sandoval 184, SGO160000), caracteres microscópicos: a, basidiosporas. b, basidios. c, cistidiolas. $\mathrm{d}$, hifas generativas. e, hifas esqueletales. Barra $=10 \mu \mathrm{m}$.

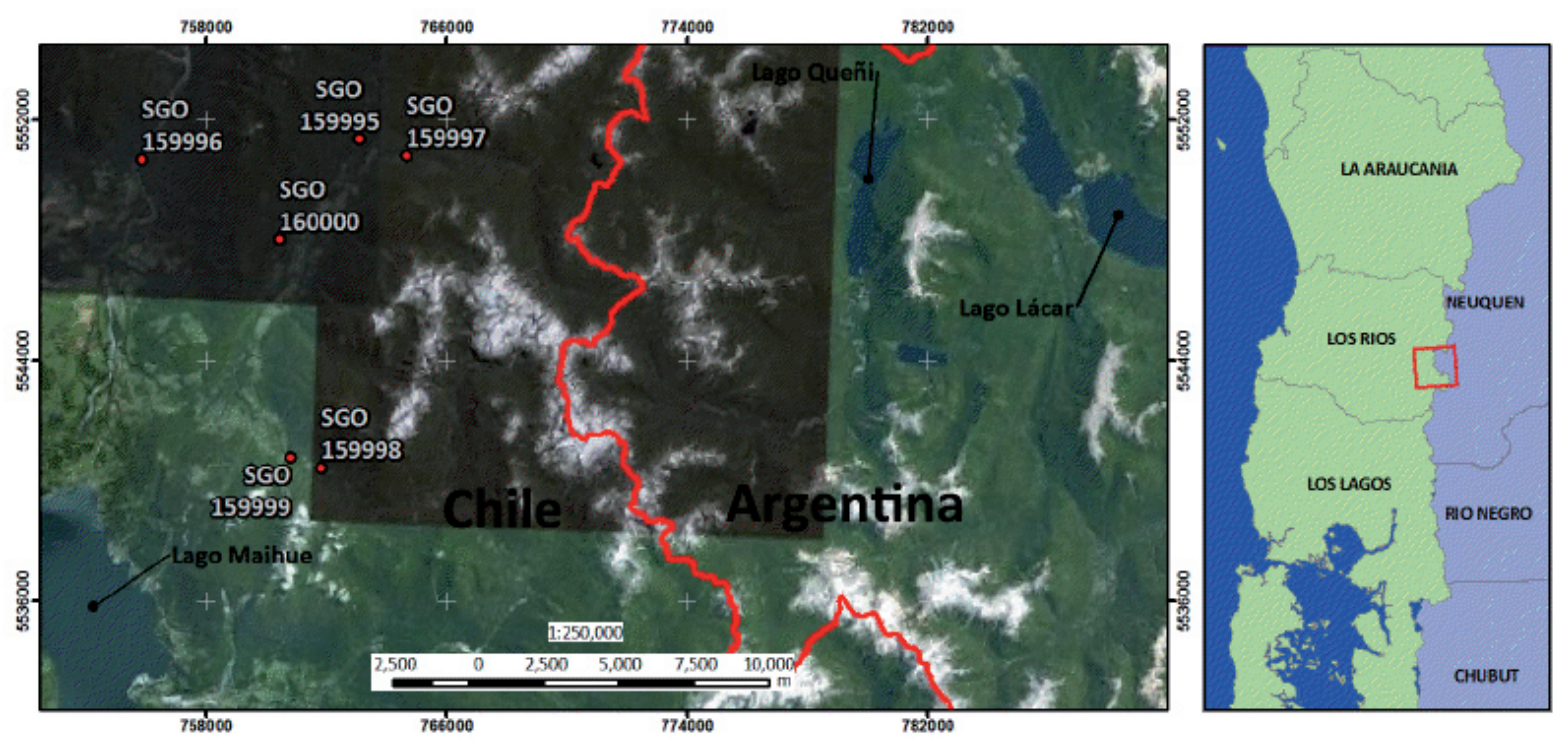

Figure 3. Collecting sites in Argentina and Chile (projection UTM, Datum WGS 1984, zone 18s).

Figura 3. Sitios de colecta en Argentina y Chile (proyección UTM, Datum WGS 1984, zone 18s). 
Specimens examined. CHILE, Región de Los Ríos, comuna Futrono, around lake Maihue. On fallen tree in forest of Nothofagus obliqua and Aextoxicon punctatum, lat. 40'9'5.23'S, long. 71'53'34.21'W, P. Sandoval 178 (Figs. 1e, 1f), 28-XI-2009 (SGO 159997). Ibid., on fallen tree in forest of Laureliopsis philippiana and Aextoxicon

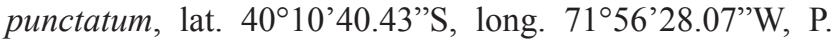
Sandoval 184 (Fig. 2), 05-II-2010 (SGO 160000). Ibid., on bridge of Nothofagus wood within forest of Nothofagus dombeyi and Eucryphia cordifolia, lat. 409'19.58'S, long. 71'59'44.18”W, P. Sandoval 185 (Fig. 1d), 09-VII-2010 (SGO 159996). Ibid., on fallen tree in forest of Nothofagus obliqua, lat. $40^{\circ} 8^{\prime} 49.21^{\prime \prime S}$, long. 71 54 '40.04”W, P. Sandoval 186 (Figs. 1a, 1b, 1c) 04-II-2010 (SGO 159995). Ibid., on fallen tree in forest of Laureliopsis philippiana and Eucryphia cordifolia, lat. 40¹4'45.38'S, long. 71'55'17.72”'W, P. Sandoval 187, 06-VII-10 (SGO 159998). Ibid., on fallen tree in a pasture with Nothofagus dombeyi, lat. 40¹4'34.84'S, long. 7156'1.19'W, P. Sandoval 189, 06-VII-10 (SGO 159999).

\section{ACKNOWLEDGEMENTS}

We are grateful to José Luis Henríquez, Luis Faúndez, Hernán Retamales and Patricio Saldivia, for their pertinent advices and help and to Jorge Márquez by his valuable help with the map. MR is researcher for the National Research Council of Argentina (CONICET).

\section{REFERENCES}

Donoso, C. 1993. Bosques templados de Chile y Argentina: variación, estructura y dinámica. Editorial Universitaria, Santiago, Chile. 484 pp.

Gajardo, R. 1994. La vegetación natural de Chile. Clasificación y distribución geográfica. Editorial Universitaria, Santiago. 166 pp.

Kirk, P.M., P.F. Cannon, D.W. Minter \& J.A. Stalpers. 2008. Dictionary of the fungi. 10th Edition. CAB International, Wallingford. $771 \mathrm{pp}$.

RAJCHENBERG, M. 1995. New polypores from the Nothofagus forests of Argentina. Mycotaxon 54: 427-453.

Rajchenberg, M. 2006. Los Políporos (Basidiomycetes) de los Bosques Andino-Patagónicos de Argentina. Bibliotheca Mycologica, 201. J Cramer, Berlin-Stuttgart. 300 pp.

Ryvarden, L. \& R.L. Gilbertson. 1993. European Polypores part 1. Abortiporus - Lindtneria. Synopsis Fungorum 6. Fungiflora, Oslo. 387 pp.

Recibido: 30.12 .10

Aceptado: 02.03.11 